\title{
INFLATION AND THE FOREIGN EXCHANGE MARKET ${ }^{1}$
}

\author{
A.Bozhechkova, P.Trunin
}

Over the period March 2015 - February 2016, the growth rate of prices declined to 8.1\%, while the corresponding index for February 2015 - January 2016 amounted to 9.8\%. As demonstrated by the results of a survey published by the Bank of Russia, in February the median inflation expectation index for the next year also declined by 1.0 p.p. to $15.7 \%$. As shown by the year-end results for 2014-2015, the plunge of the nominal effective exchange rate of Russia's national currency was much more dramatic than the downward movement of the national currencies of the other countries - exporters of raw materials, although their terms of trade were also deteriorating at a comparable rate.

The sharp plunge of the ruble's exchange rate against the world's major currencies in late 2015 - early 2016 gave rise to fears that this year we were going to experience yet another surge in inflation. However, so far the growth rate of consumer prices has continued to be on the decline. The Consumer Price Index in February 2016 rose on the previous month by $0.6 \%$ (vs. 2.2\% in February 2015), and over the period from March 2015 through February 2016 it gained $8.1 \%$, while in January its value in per annum terms had amounted to $9.8 \%$ (Fig. 1). In February, core inflation ${ }^{2}$ amounted to $0.7 \%$, having gained 0.1 p.p. on the previous period, besides, the core inflation index for that month rose 0.1 p.p. above the rate of growth of the Consumer Price Index. On the basis of these data it can be concluded that the upward pressure on prices was exerted in the main by seasonal factors.

In February, for the first time since September 2015, the growth rate of prices of foodstuffs declined, to $0.7 \%$. In this connection, under the influence of the seasonal factor, the prices for fruit and vegetable products displayed the highest surge. The growth rate displayed by the prices of nonfood commodities, on the contrary, rose to $0.8 \%$, which is a manifestation of the strong effect of the situation in the forex market, which had been pushing up, first of all, the prices of household utensils. It should be noted that for the first time since June 2012, the input of the nonfood commodity group in the movement of CPI was the biggest by compari-

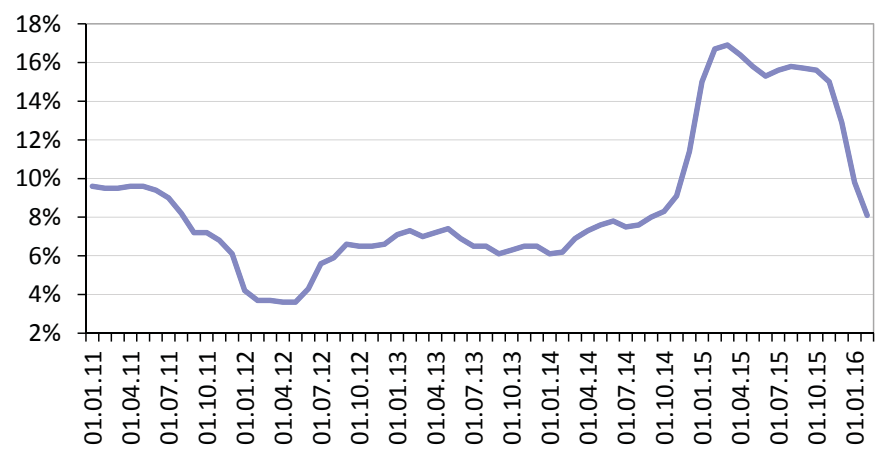

Source: Rosstat.

Fig. 1. The CPI Growth Rate over 2011-2016, \% per Annum

1 This paper was originally published in Online Monitoring of Russia's Economic Outlook No. 4(22).

2 The core consumer price index reflects the level of inflation on the consumer market after adjustment for the seasonal factors (prices of vegetable and fruit products) and administrative factors (regulated tariffs for certain types of services, etc.). This index is also calculated by the RF Statistics Service (Rosstat). 
son with the inputs of all the other components of $\mathrm{CPI}$, amounting to $42.9 \%$ (Fig. 2). The prices and tariffs established for commercial services rendered to the population in February increased by $0.3 \%$, and so their input in CPI growth amounted to $26.7 \%$.

As demonstrated by the results of a survey published by the Bank of Russia, in February the median inflation expectation index for the next year, after having been in the rise for three previousux months in a row, also declined by 1.0 p.p. to $15.7 \%$. Inflation expectations remain high, and so there exist significant risks that inflation might rise above the target set by the RF Central Bank in its forecast for 2016 (5.5-6.5\%). Besides, it should be borne in mind that the rapid decline, early in 2016, of the inflation index that had been climbing over the previous 12-month period can be explained first of all by its high core value observed in early 2015, when it surged in response to the pass-through effects of the ruble's exchange rate decline in Russia's sector of consumer goods and services.

An upward pressure on inflation may also be exerted by the accelerated growth rate of money aggre-

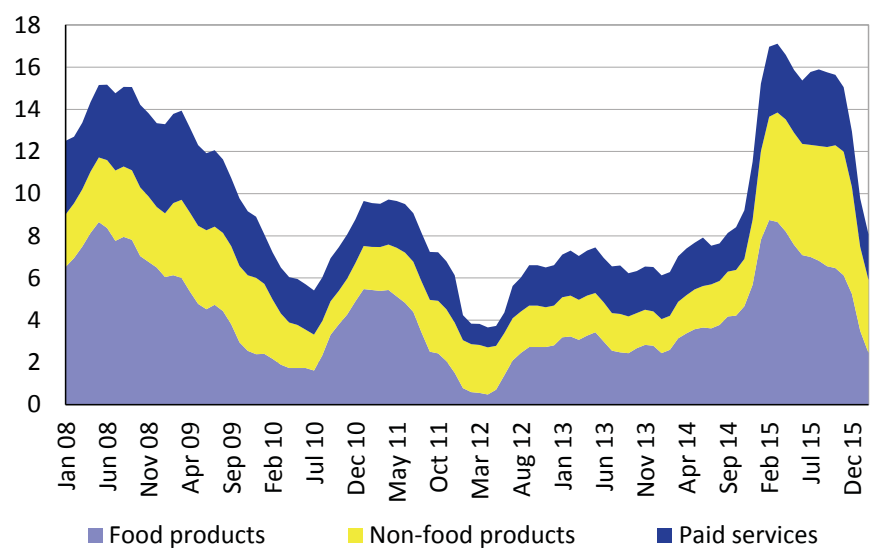

Source: Rosstat.

Fig. 2. Inputs of CPI Main Components in 2008-2016, in per Annum Terms over Period 2008-2016

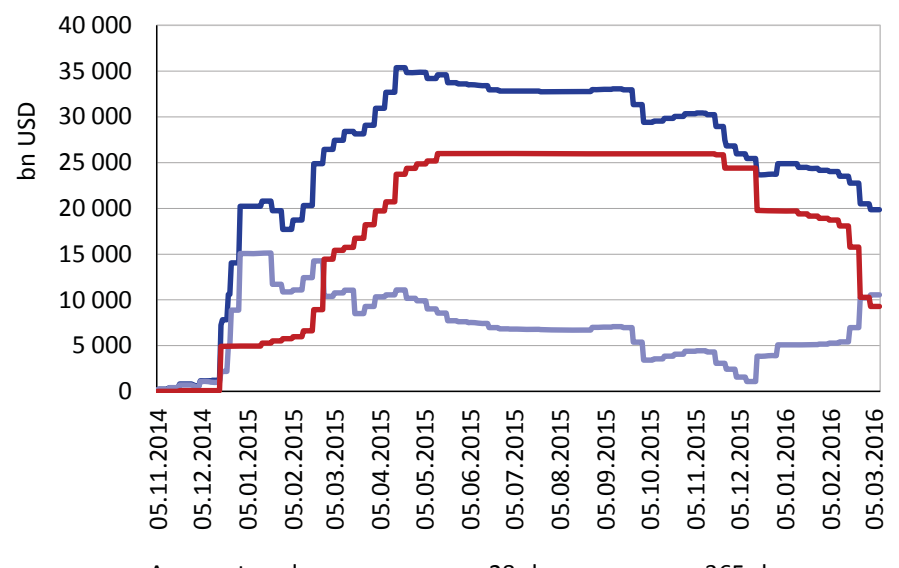

Source: Bank of Russia.

Fig. 3. The Amount of Banks' Repo Debt to the RF Central Bank Denominated in Foreign Currencies in 2014-2016 gate $M 2$, which has become evident over recent months. Thus, over H2 2015 this index rose from 7\% to $11.5 \%$ in per annum terms (on the corresponding month of the previous year). Money supply has been on the rise, among other things, because the RF Ministry of Finance has been spending the RF Reserve Fund. Inflation can be brought down somewhat if the ruble's strengthening, observed over February-March 2016, should prove to be sustainable.

It should be noted that, in spite of the significantly weakened national currency, the RF Central Bank continued its policy of non-involvement in the situation on the foreign exchange market. Moreover, in the course of the month of February the volume of its international reserves increased by $2.4 \%$ to $\$ 380.5 \mathrm{bn}$ as of 1 March 2016. The growth of international reserves resulted in the main from the repayment, to the Bank of Russia, of the loans denominated in foreign currencies by the resident banks. In February, the volume of foreign currency obtained as repo loans by banks from the RF Central Bank shrank by $15.1 \%$ to $\$ 20.5 \mathrm{bn}$ ( $\$ 24.2 \mathrm{bn}$ as of the end of January 2016), including $\$ 9.3 \mathrm{bn}$ ( $\$ 18.9 \mathrm{bn}$ as of the end of January 2016 ) for 365-day operations 
and $\$ 10.6 \mathrm{bn}$ ( $\$ 5.2 \mathrm{bn}$ as of the end of January 2016) for 28-day operations (Fig. 3). These changes in the structure of the banking sector's debt, denominated in foreign currencies, to the RF Central Bank occurred because from 14 December 2015 onwards the Bank of Russia resumed its 365-day FX REPO auctions, while at the same time raising the cut-off rate to LIBOR +3 p.p. (previously it had been set at LIBOR $+2,5$ p.p.). Over the period from 1 January through 9 March, 365-day FX REPO auctions were held 9 times, and only three of them managed to find bidders (with the volume of attracted funds amounting to $\$ 29.2 \mathrm{~m}$ at an average rate of $4.2 \%$ per annum), which can be explained by the high cost of funding. Commercial banks were much more willing to participate in 28-day FX REPO auctions. Thus, over the period from 1 January through early March 2016, a total of $\$ 18.8 \mathrm{bn}$ at an average rate of $2.5 \%$ per annum was borrowed in the framework of such auctions.

So, in spite of yet another plunge of the ruble's exchange rate in late 2015 and early 2016, the substantial sums paid to redeem Russia's foreign debt in December (the repayments of principal debt in the amount of $\$ 21.9 \mathrm{bn}$, and scheduled interest payments in the amount of $\$ 2 \mathrm{bn}$ ), and the increase in the US Federal Reserve's interest rates, the demand of banks for refinancing their loans denominated in foreign currencies is on the decline. In all probability, credit institutions are not experiencing any shortage of their foreign exchange resources accumulated over the course of last year.

On the whole, the low demand for foreign currency displayed by banks is indicative of the persistently stable situation in the foreign exchange market and the low probability of a panic similar to that observed in late 2014. So far, the movement pattern of the ruble's exchange rate has been determined by that of prices of oil. Thus, as a result of the rise in Brent oil prices from $\$ 33.98$ per barrel in early February to $\$ 40.88$ per barrel as of 12 March, the ruble-toUSD exchange rate gained $7.9 \%$ and rose to 70.3 (Fig. 4).

In general, over the period 2014-2015, the plunge of the ruble's real effective exchange rate was much deeper than that of the national currencies of the other major exporters of raw materials. For reference: over the period 2014-2015, the real effective exchange rate of the Russian ruble dropped by $39.1 \%$, that of the Brazilian real by $27.3 \%$, that of the Canadian dollar by

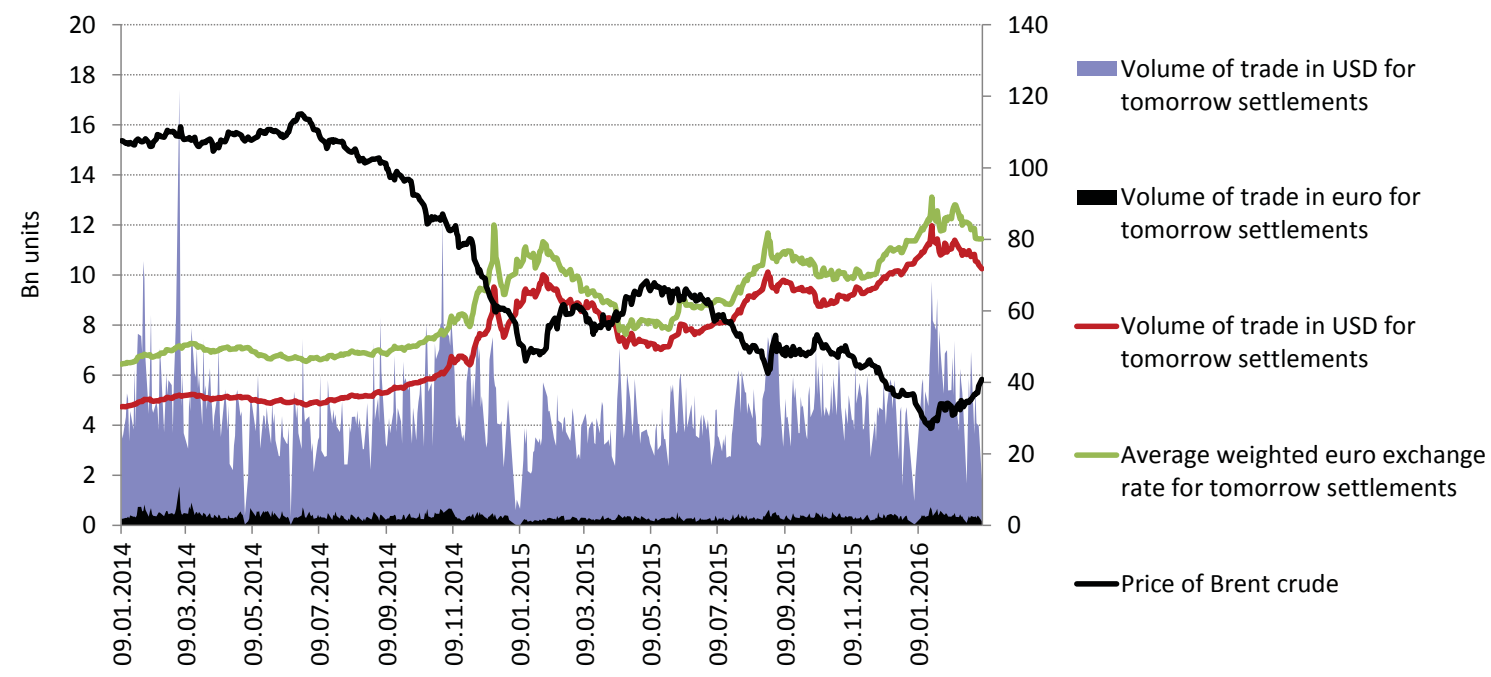

Source: RF Central Bank, ICE.

Fig. 4. The Situation in the RF Forex Market and the Movement of Oil Prices in 2014-2016 


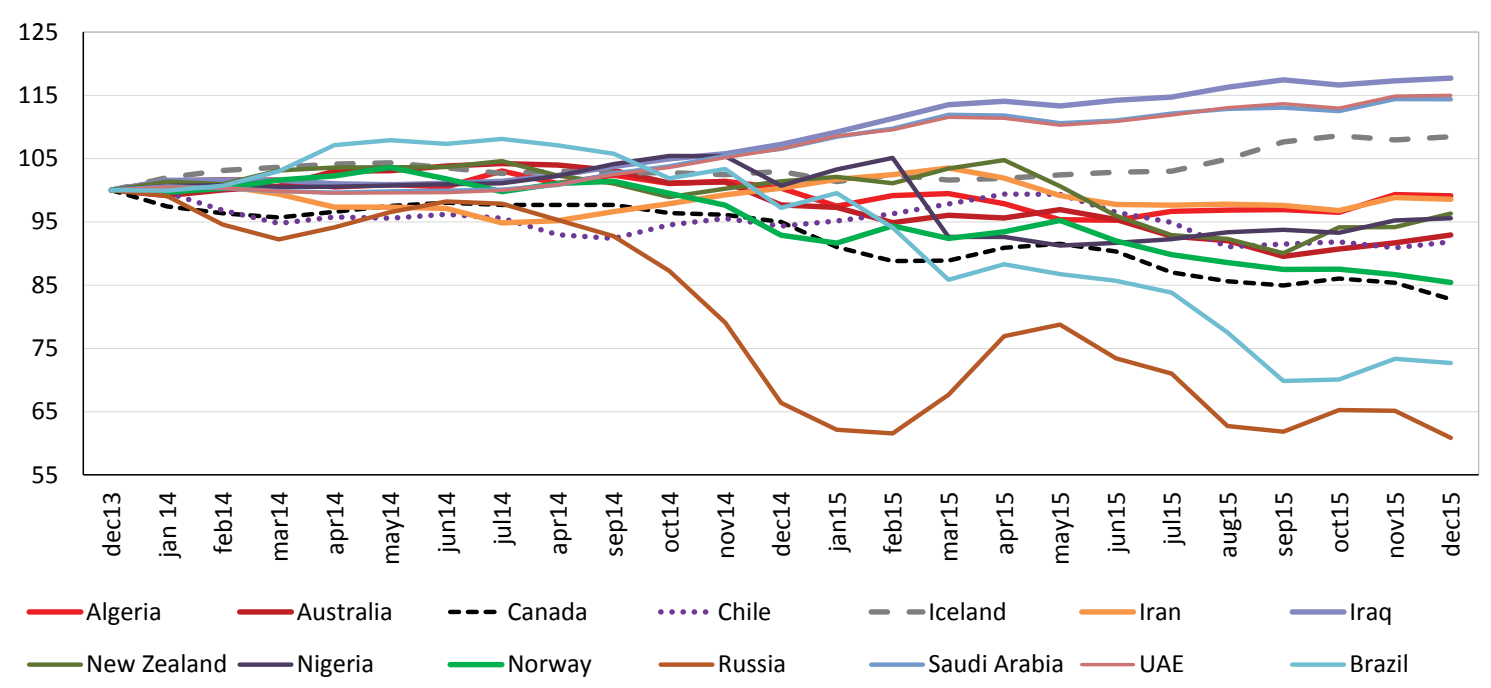

Source: IFS, BIS.

Fig. 5. The Movement, over Period 2014-2015, of the Nominal Effective Exchange Rates of the National Currencies of the World's Major Exporters of Raw Materials

(December $2013=100)$

$17.3 \%$, that of the Norwegian krone by $14.6 \%$, that of the Chilean peso by $8.2 \%$, and that of the Australian dollar by $7.1 \%$ (Fig. 5). Over that period, the terms of trade for the Russian economy lost $21.7 \%$, while the same index for Norway amounted to $24.3 \%$, and that for Australia - to $16.2 \%$.

At the same time, if data for 2015 are taken separately from data for 2014, the downward movement of the Russian ruble's exchange rate was comparable with the depreciation rates of the national currencies of the other major exporters of raw materials. Thus, over the course of 2015, the ruble's exchange rate dropped on December 2014 by $8.4 \%$, that of the Norwegian krone by $8.1 \%$, that of the Australian dollar by $4.9 \%$, that of the Canadian dollar by $12.9 \%$, and that of the Brazilian real by $25.2 \%$ (Fig. 5). Over the past year, the Russian economy experienced a $19.9 \%$ deterioration in its terms of trade, while for Norway this index lost $9.0 \%$, and for Australia - 12.4\%.

Data for the first three quarters of 2015 indicate that most of the rawmaterial exporting countries experienced a notable decline of their trade balances (Table 1). However, the less steep plunge displayed by their national currencies over the period 2014-2015 alongside the downward movement of their current account balances can be explained by the much weaker pressure exerted on their foreign exchange rates by the financial accounts of their balances of payments (Norway, Australia, Canada), which in the Russian Federation was very strong. The other factor is the spending of their international reserves in order to sustain the fixed exchange rates of the national currencies in the Middle East.

Thus, the sharp plunge of the Russian ruble's exchange rate in late 2014 early 2015 was caused, most probably, by the panic in the forex market caused by uncertainty with regard to the prospects for Russia's economy in view of the continuation of international economic sanctions and high geopolitical risks. As a result of the Bank of Russia's switchover to a freely floating foreign exchange rate of the national currency, currently its exchange rate is determined by the basic market factors that shape the supply of and demand 
for the national currency in the forex market, and first of all by prices of oil, as well as by the rates of return on assets denominated in the national and foreign currencies, with due regard for the associated risks. The truth of such a conclusion is confirmed, among other things, by the way the situation in the forex market was evolving in late 2015 and early 2016, when the rate of decline of the ruble's exchange rate against the USD was comparable with the movement patterns displayed by the national currencies of the other developing countries, and so the situation did not translate into a foreign exchange crisis similar to that observed in late 2014.

Table 1

\section{THE COMPONENTS OF THE BALANCES OF PAYMENTS OF THE COUNTRIES} EXPORTING RAW MATERIALS, BN USD

\begin{tabular}{l|c|c|c|c|} 
& \multicolumn{2}{|c|}{$\begin{array}{c}\text { Balance of foreign trade in } \\
\text { goods and services (bn USD) }\end{array}$} & \multicolumn{2}{|c|}{$\begin{array}{c}\text { Financial account bal- } \\
\text { ance (bn USD) }\end{array}$} \\
\cline { 2 - 6 } & 2014 & Q1 to Q3 2015 & 2014 & Q1 to Q3 2015 \\
\hline Australia & -9.1 & -16.3 & 45.4 & 34.4 \\
\hline Canada & -16.2 & -21.3 & 38.9 & 31.9 \\
\hline Chile & 4.0 & 1.0 & 3.8 & 3.8 \\
\hline Iceland & 1.1 & 1.1 & 5.8 & -0.9 \\
\hline Brazil & -15.0 & -18.0 & 111.4 & 51.7 \\
\hline New & 2.2 & 1.6 & 3.1 & -3.7 \\
Zealand & & & & \\
\hline Norway & 43.7 & 11.7 & -55.4 & -4.4 \\
\hline Russia & 134.5 & 86.1 & -130.2 & -58.0 \\
\hline Saudi Arabia & 96.0 & -15.5 & -57.4 & -47.4 \\
\hline
\end{tabular}

Source: IFS, Central Reserve Bank of Peru. 